\title{
The Gender and Development (GAD) Paradigm: Empowerment of Rural Afghan Women through Collaborative Initiatives
}

\author{
Samar Khan \\ School of Environmental Design and Rural Development, University of Guelph, Canada
}

Copyright $(2016$ by authors, all rights reserved. Authors agree that this article remains permanently open access under the terms of the Creative Commons Attribution License 4.0 International License

\begin{abstract}
The objective of this study is to explore the plight of Afghan women during the Taliban era, and how they managed to overcome gender-specific barriers through cooperative initiatives thereby developing and empowering each other. For this study, a literature search was undertaken by using various electronic research databases to understand the Gender and Development (GAD) paradigm in the context of Afghan women in Afghanistan, as well as to examine how two decades of war, invasion, and violent conflict has affected the lives of these women. The literature search determined that despite the horrific conditions for women in Afghanistan, they were still able to organize gender-related survival strategies and, in the process, become aware of more gender-specific concerns. Participatory Rural Appraisal (PRA), the Identities of Women Framework (IWF), and bottom-up development initiatives were just some of the useful tools that were utilized to appropriate quantitative and qualitative analyses of the needs of rural women in Afghanistan. As such, women collaboratively worked together, in groups and organizations, to generate networks, norms, and trust in their communities. This was established not only through aid/assistance but also through partnerships with national and international women's organizations, women's media, and non-government organizations (NGOs). This review thus aims to inform that joint ventures have enabled rural Afghan women to feel more empowered and break taboos, thereby working towards changing gender relations and perceptions at a much deeper level.
\end{abstract}

Keywords Afghanistan, Afghan Women, Development, Empowerment, Gender

\section{Introduction}

The area of gender and development (GAD) has been the site of many debates, discussions and critical contributions to the field of development studies in the past few decades [1]. The GAD paradigm emerged in the 1970s, during a time when socialist feminists critiqued liberal feminist efforts to create a greater role for women in development [2]. GAD approaches also took form in feminist academic thought and in feminist activism, where women were seen as being actively involved in the development process [3]. Some early development planners considered women as a symbol of traditional culture and thus an economic and developmental liability [4]. It was up until the1970s that the prevailing policy, which addressed women primarily in their roles as wives and mothers was what was known as the 'welfare approach' [3]. However, it was during this time that a shift to women in development (WID) approaches transpired, which was informed by feminist theory and the women's movement; it was further associated with the UN Women's Decade (1976-1985)[5]. As a result, the GAD paradigm acquired a central place in many studies regarding the impact of development and modernization on women in developing societies [6].

Furthermore, Boserup's (1970) study on women's role in economic development also set the stage for research on the ways in which women's roles have changed during economic and social development [7,8]. Such gender-focused studies, along with feminist arguments about the social construction of gender and gender hierarchies, emphasized both women's potential as economic assets, as well as the social forces that tended to often resist women's contributions in society [6].

Consequently, this study will attempt to look at the GAD paradigm in the context of Afghanistan, and examine the ways in which it applies to rural Afghan women. The plight of Afghan women has attracted worldwide attention especially during the Taliban regime (1996-2001) when particularly harsh policies were enacted in their regard. Though, it can be argued that their "subordinate" position did not necessarily start with the Taliban. The regime brutally tried to impose extremely strict customs on the whole society, resulting in Taliban-like conditions that have prevailed, and 
continues to prevail, in many parts of the country, especially in rural areas, and more particularly in Pashtun ${ }^{1}$ communities. While survival strategies are deeply embedded in the material conditions of life, it is usually the poorer rural sections of Afghan society which remain in the war-stricken areas during the times of violent conflict, while those with economic opportunities usually migrate elsewhere. In spite of this, significant minorities of professional and educated Afghan women remained in Afghanistan, or have returned to their country, in hopes to aid and create networks with more unfortunate Afghan women that are living in the country.

This paper will hence provide an analysis of the GAD paradigm by addressing the issue of gender inequality, especially in the context of rural Afghan women living in Afghanistan. The ways in which Afghan women used survival strategies, such as the formation of networks and groups in solidarity with the poor rural women, will also be explored. This is because, according to Rostami-Povey [9], for over 20 years, these networks and forms of solidarity became mechanisms for the empowerment of rural Afghan women, especially under the Taliban rule.

\section{Research and Discussion}

\section{Gender Equality and Economic Growth through Women's Organizations and NGOs}

Gender inequality is widely recognized as the most prevalent form of social disadvantage in many developing societies. Relative to men, women (for e.g. Afghan women) have lower status in the family, community and public spheres; have less political power; less economic autonomy; less earning power; and less access to resources (e.g.: money, education, credit, training) that bring status and prestige [3]. They also carry a heavy and uneven burden of work and are more vulnerable to violence - to what has been termed a "global epidemic" of violence against women. Although the forms and the degree to which inequality is manifested vary from society to society, in most developing societies, women's and men's responsibilities, opportunities, and influences are clearly unequal [3].

One of the most challenging assumptions, in development studies and policy-making, is that economic growth contributes to gender equality, and this is clearly exhibited in the north but gravely lacking in the south. However, the solution that has been proposed to such an assumption is that policy prescriptions that have generated growth in the industrialized north can be applied to the countries in the south [3]. It is further assumed that compared with women in the north, women in the south are in a much weaker position to benefit from opportunities to enter the workforce. In the case of low-income, illiterate/uneducated women, the situation is bleaker as the implementation of such policies can further reinforce existing inequalities or create new

1 A prominent ethnic race that speaks Pashto and constitutes a majority (about $60 \%$ ) of Afghanistan. forms of inequalities [3].

As a result, activists in academia and non-government organizations (NGOs), from both the industrialized north and the third world countries of the global south, sought to mobilize and demand action in order to promote gender equality. This allowed for the creation of a number of international women's NGOs, which included the following:

- Development Alternatives for Women in a New Era (DAWN)

- The Women's Environment and Development Organization (WEDO)

- Women in Development Europe (WIDE).

Additionally, UN agencies such as the Development Fund for Women (UNIFEM), the Research Institute for Social Development (UNRISD), and the Population Fund (UNFPA) have also been central to carrying out research, conducting gender analyses, and implementing programs aimed at gender equality and women's empowerment. These organizations have managed to shed light on a wide range of important issues, which include sexual/domestic violence, reproductive rights to health, child mortality, sexual orientation, trafficking of women, and the global sex industry. These organizations have also drawn attention to concerns regarding women and the economy in the context of globalization [3].

Further, the above-mentioned women's organizations play a critical role in advancing gender equality, economic growth of women, and women's empowerment by providing support and defending groups of women who are vulnerable. They are also helping in providing community-based education, ensuring that women's rights issues are recognized by policy-makers, included in legislation and constitutions, as well as holding governments accountable with regards to the implementation of these rights for women [3].

\section{GAD's Contribution to Development Practice}

\section{1) The Identities of Women Framework (IWF)}

Singh[6] argues that one of the methods in which participatory planning may contribute to gender equality and empowerment is the interdisciplinary approach to understanding identities of women. The approach is based on three premises that she proposes as follows:

a) a rejection of the generalization about women's identity; b) an acceptance of women's unique place within the framework of specific and time-bound socio-cultural contexts; and, c) an acknowledgement of an individual woman's ability to have multiple identities and to negotiate new ones. [6: p. 105)

This means that personal narratives, or life stories, of women can be used as an example of their expressed identities [6]. Life stories may include autobiographies and personal letters that highlight the experiences and expressions of women, and the ways in which they differ from one another despite being in the same social context. 
This notion is further drawn upon personal socialization histories and social contexts of poverty and religion; interpersonal relationships, which include those with family; local histories, such as cultural revolutions and social movements; and, state structures and policy [10]. Personal narratives hence serve as the actual voice of the women themselves, as they are able to reflect the subtle differences between other individual women [6].

\section{2) Participatory Rural Appraisal (PRA)}

Another effort to promote participation and gender equality in development is the participatory rural appraisal (PRA) method, which is a widely used participatory technology that has become popular as a tool for planning over the last decade, either to identify priorities or to contrast community action plans [11]. Developed primarily by Robert Chamber, PRA is a practice-oriented method of development that, according to Kapoor [12: p. 101], "aims at enabling local people and communities to take control over their own development." It uses local knowledge and participation to give people, especially women, a role in planning and a chance to contribute to their own learning process; it also relies on innovative communication and community development practices to achieve these objectives. The underlying premise is that participation by all members of the community will improve development efforts [11]. The core principle of the PRA method is thus to allow unheard voices to be heard, and to provide individuals or groups of people with a sense of purpose and agency.

It appears that the Identities of Women Framework and PRA share a number of similarities, such as emphasis on women's participation and free-form implementation. Yet, despite these similarities, the Identities of Women Framework and PRA have different objectives. PRA uses social action and gender participation to facilitate communal development, whereas the Identities of Women Framework advocates social action and participation as a means to achieve agency solely for the individual woman, but neither supports nor opposes the development of groups of women [12].

However, PRA is not without flaw, for it certainly requires institutional commitment to support a longer term process of social change rather than simply relying on "quick fix" development solutions [11].

\section{3) Bottom-up Development}

Another important aspect of participatory planning and development involves what is known as 'bottom-up development'. Razavi and Miller [2] explain that the process of bottom-up development, promoted by some women and development advocates, focuses on collective action. Here NGOs are seen as playing a central role in organizing women for collective action. Though this notion has been criticized as it places women in a homogenous category like "the community" and further perceives them only within "the feminine" essence (as being non-hierarchical, conflict-free, etc.). Further, much thought on women's NGOs pertains to the denial of the cultural and historical construction of gender. It is instead believed that the reason women are missing from the development realm is largely due in part to the underlying notion of common "real interests," and the many "problems" that accompany feminist collective action [2].

Similar assumptions are understood in some analyses of women's organizations and NGOs where the issue of conflict, for example, is at times brushed aside, as women's groups are urged to become democratic [2]. There seems to be little recognition that organizational politics and struggles are as likely in women-only organizations as in mixed-gender ones. In the same way that women take their gender identities with them into "impersonal" markets, they also take their other identities with them into women's organizations - hence, making both conflict and hierarchy inevitable between them [2].

However, this doesn't imply that collection action is a failure altogether; as a matter of fact, it is quite a success for women in many developing societies. Women use kinship and non-kinship links to co-operate across households farming each other's fields, helping with childcare, sharing their life savings to cover for major life cycle events (such as marriage), or for productive investments [13,14]. Many of these groups or arrangements are informal and have evolved as coping mechanisms through which women try to escape some of the constraints of their economic, as well as cultural, circumstances. Bottom-up development is especially appropriate for targeting marginalized women, such as widows, single mothers, former commercial sex workers, refugees, internally displaced women, and women with HIV/AIDS [15].

Nevertheless, the point of illustrating some of the limitations of women's organizations and NGOs is not to undermine their importance. Rather, Razavi and Miller[2] argues that a more critical approach to the strengths and weaknesses of NGOs would help women and development advocates to clarify their thinking on participatory planning and bottom-up strategies.

\section{Collaboration of Urban and Rural Afghan Women}

Although twenty-two years of war and violent conflict has marred social capital in Afghanistan, women are still able to organize gender-related survival strategies and, in the process, become aware of more gender-specific concerns. Participatory Rural Appraisal (PRA) [16] and Afghan women's stories provided some useful tools for an appropriate quantitative and qualitative analysis of the needs of rural women in Afghanistan. These women, particularly, work together in groups and organizations by generating networks, norms, and trust in their communities [9]. Also, the provision of resources and opportunities for women to tell and share their stories/experiences through the Identities of Women's Framework (IWF), as part of a healing process, is a vital element in the post-war reconstruction effort. These stories explain how some Afghan women, by moving into 
the space of agency, deconstructed the world which was created for them - by Diaspora and by imperialist invaders. Their voices are the voices of many women, as they challenge the male conception of the world by voicing their own identity [17]. Though, many women may not want to voice the truth about what they'd gone through, for fear of wider personal and political reprisals, especially sex workers in the context of the very strict Islamic law, which strongly condemns prostitution. Because if a woman is caught prostituting herself, she is severely punished through the death penalty [9].

Nevertheless, many prominent Afghan women prominent as in women who are highly educated and wealthy enough to live abroad - chose to stay in Afghanistan and work, either openly or secretively, towards empowering the poorer, rural women (as well as children) in the country. Rostami-Povey [9] provides an example of Soraya Parlika head of the National Union of Women of Afghanistan - who became an integral part of the women's movement there:

We witnessed twenty-two years of war, terror and bombing. We have an ancient saying: 'It is one thing to hear about something, but quite another to see it with your own eyes'. Under the Mujahidin ${ }^{2}$, the weapon of one community against another was to attack, to jail, to rape, to hit in public the female members of the other community. Under the Taliban, women were denied their basic rights to education. Throughout, we continued our activities, openly and secretly, and this allowed us to hold hands with each other and survive. [9: p. 269]

Other examples include the non-governmental Women's Vocational Training Centre, which has been active for 20 years and has offered women in Kabul courses in English and German, as well as computer skills courses. Additional courses included acquiring skills in handicrafts, embroidery, bee-keeping, honey-making, and animal husbandry in rural areas outside of Kabul. During the Taliban rule, the Women's Association of Afghanistan funded and managed secret sewing, knitting, and handicraft courses for women. As Shafiqa Habibi, a leading member of this organization, explained:

These courses took place in the homes of the teachers. Sometimes we had to change our venue for fear of persecution by the Taliban, but we continued. Our activities enabled many women to make clothes and other necessities for themselves and their families, and sometimes they sold or exchanged their products with other women. [9: p. 270]

As for the majority of poor women in rural areas, they never left Afghanistan. Those with the necessary skills turned their homes into underground schools. They were compensated for these services by their families, friends, as well as their neighbours. This was the way they were able to survive financially [9]. Networking and group solidarity

2 This is an Arabic term which refers to those who engage in the Islamic holy war known as "Jihad." According to the Wikipedia definition, it was used to refer to the guerrilla type military outfits led by the Muslim Afghan warriors in the Soviet war in Afghanistan, but now it is not limited to Afghanistan anymore and includes other countries as well. enabled these women to remain in touch with each other. Many Afghan women engaged in teaching girls, young women, and some boys in their neighbourhoods; while others hid their books, notebooks, and pens/pencils under their burqas ${ }^{3}$, thus risking their lives by going to the "secret" schools every day. The level of trust and support generated by these secret organizations was measured by the widespread incidence of teaching in women's homes and the support they gave each other to ensure the survival of these secret meetings [9]. Of course, many women involved in education were caught by the Taliban. Yet, even though they were persecuted, jailed, and tortured, they continued with their astringent struggle. As Marzia Adil, a journalist, shares the following story:

Hadeya Malekzad taught 150 students in her home. Despite many threats from the Taliban, she continued her work. Now she is the leader of a group of women in her area and discusses with them the significance of education and employment. In a meeting with Soraya Parlika, the head of the National Union of Women of Afghanistan, 3000 women gathered together on top of one of the hills around Kabul to raise their demands with [her]. [9: p. 272]

Despite detrimental conditions of life under the Taliban, many Afghan women pulled themselves from the depth of seclusion and oppression, and found a space to exercise autonomy and agency. They broke the predefined spaces of confinement and silence. They contested the idea that Muslim society is about building barriers to shut women out, condemning them to a life of oppression and subjugation [17]. Women's activities were mainly concentrated on running secret schools, thus meeting the practical gender needs of women $[18,19]$. These women risked their lives to create purpose and unity within their communities, and they had the support of other women in the community to be successful as well. As a matter of fact, during the Taliban regime, many women felt much closer to each other and were more motivated to work and bring change to their communities than under the US-led invasion. In the post-Taliban period, they began to move towards addressing women's strategic interests by challenging patriarchal gender relations in Afghanistan. They also challenged the Western perception of Muslim women, especially with regards to the burqa [9].

Moreover, Kandiyoti [20] states that there were some community participation and leadership roles among women, which frequently escaped Taliban detection, and the reason was because they did not take place in public arenas commonly associated with modern civil society. The politics of alliances and reputation played a central role in the tribal and village societies, and women participated in decision-making through important roles in matchmaking, gift exchange, and participation in life cycle rituals. Advancing age, religious learning, and membership in

3 The burqa is an outer garment worn by women in some Islamic societies, in which they are required to cover their whole bodies, including the face and hands, when in public. 
powerful lineages also created considerable authority in rural Afghan women [20].

\section{Afghan Women Leaders/NGOS and the Reconstruction Process}

Afghan women believe that the process of reconstruction must take into consideration the gender dimension of the needs of both women and men. They also believe that it is imperative to build a channel of communication through bottom-up development strategies between women leaders and ordinary/rural women, as well as creating links among women and women's groups, which include those who are facing repression. During the violent conflict imposed by the Taliban, women's NGOs managed to remain in touch with each other and with female members of the community through networking and solidarity groups. In the post-Taliban era, these groups have indeed become important agents for reconstruction, where women's NGOs played an eminent role, particularly with regards to education and skills training. Women's NGOs were involved in the creation of social and economic opportunities for rural women, which included activities related to income generation, thus contributing to their overall well-being in both the household and community [9].

Further, because many of the educated Afghan women have been employed in aid agencies, they were able to contribute to the reconstruction process by acquiring and using their expertise (through their work with NGOs) to help rural women in displaced communities. The following are Afghan women's NGOS run by women, as proposed by Riphenburg [21]:

- Afghan Women's Resource Centre

- Afghan Women's Education Centre

- Health and Development Centre for Afghan Women

- Women's Development Program for Afghanistan

- Women's Welfare Department

- Afghan Institute for Learning

Additionally, Riphenburg states that potential networks of women in government and aid agencies are as follows:

- Afghan Women's Network (AWN)

- Afghan Women Empowerment Program (AWEP)

- Physiotherapy and Rehabilitation Support Afghanistan (PARSA)

- Swedish Committee for Afghanistan (SCA)

- Cooperative for Assistance and Relief Everywhere (CARE)

- Women's High Association (WHA) and Habitat

\section{International Donor Organizations}

Alongside the creation of national mechanisms for the advancement of rural Afghan women, the response of the international donor community, on the other hand, has also desired to include a women's participation component into their programs and projects [20]. In terms of community-led participation, one of the most complicated social experiments in Afghanistan is the National Solidarity Programme (NSP). The NSP is based on a participatory approach to local level development through democratic and representative Community Development Committees (CDC) at the village level [22]. However, men's strong belief that women lack necessary 'knowledge' to participate in decision-making (except in daily matters with regards to the household) provides a powerful justification for their exclusion from customary bodies of local government, dispute settlement, and arbitration such as tribal jirgas (councils), which often tend to be male-dominated [23]. Yet, the creation of committees, such as CDC, was intended to provide important insights into the types of accommodation (made by local communities) to comply with donor requirements for women's inclusion in community decision-making. It was further meant to reject any assumptions that women lacked knowledge or the ability to participate in these committees, while at the same time ensuring the promotion of gender equality in the public realm [24].

Nevertheless, it is important to note that the dilemmas posed by participatory approaches in the GAD paradigm and gender-awareness interventions are by no means unique to Afghanistan [11, 25, 26]. Practioners everywhere seem to be caught between the dangers of unintentionally planning and combining existing power structures, on the one hand, or importing categories and methods that either have little significance or draws resistance at the local level, on the other [20]. This is one of the major weaknesses of donor-led state-building and reconstruction, which is a lack of emphasis on Afghan 'ownership', where the need to increase popular participation in order to 'ease the gap' between perceptions of a "modern" state with its corresponding elite and a "traditional" tribal people [27: p. 1].

Further, what is sometimes conveniently overlooked is that Afghan women, however marginalized, more than often do not share the same political culture as the men of their communities (including views about women's appropriate place and conduct), or even of those from the "modernized" north. Leaving aside the issue of whether the social forces represented in the state apparatus are necessarily "modern," the central conundrum, according to this perspective, is that traditional rural population should equate Western-driven modernization with secularization, which serves to be contradictory in the grander scheme of things. Thus, populist compromise in GAD must go through accommodating what is deemed to be 'Islamic', and be wary of traditional sensibilities, considering that Afghanistan is a predominantly Islamic republic, in order to ensure its lasting success in the country.

\section{Conclusions}

This paper aimed to examine some of the main trends in the way women's issues have been conceptualized in the context of the gender and development (GAD) paradigm, using Afghanistan as a means for analysis [2]. Achieving gender equality requires action by governments and other 
development institutions, as well as the participation of marginalized women, community and nongovernmental organizations [3].

Furthermore, participatory approaches in GAD have much to offer, but will only make a difference if they are used with sensitivity to issues of difference. What is needed are strategies and tactics that will take account of the power effects of difference, combining advocacy to handle open spaces for voice, with processes that will enable women to recognize as well as use their agency. This agency may be articulated either by creating rules of interactions in public spaces, enabling once silenced participants to exercise voice, or reaching out to "outside forces" in order to democratize decision-making processes. Such processes can therefore help transform the GAD paradigm and gender relations (particularly women) by creating more productive alliances that will address issues related to power and oppression in developing countries such as Afghanistan.

\section{REFERENCES}

[1] Marchand, M. (2009). The Future of Gender and Development after 9/11: insights from postcolonial feminism and transnationalism, Third World Quarterly, 30(5), 921-935.

[2] Razavi, S. \& Miller, C. (1995). From WID to GAD: Conceptual Shifts in the Women and Development Discourse, United Nations Research Institute for Social Development, United Nations Development Programme, Occasional Paper, $1,1-45$.

[3] Taylor, M. (2003). Gender and Development.

[4] Young, K. (1993). Planning development with women. New York, St. Martin's.

[5] Derbyshire, H. (2002). Gender Manual: A Practical Guide for Development Policy-Makers and Practioners, Social Development Division. DFID.

[6] Singh, S. (2007). Deconstructing "gender and development" for "identities of women," International Journal of Social Welfare, 16, 100-109.

[7] Haider, R. (1995). A perspective in development. Dhaka, Bangladesh, University Press.

[8] Momsen, JH. (2004). Gender and development. New York, Routledge.

[9] Rostami-Povey, E. (2003). Women in Afghanistan: passive victims of the borga or active social participants?, Development in Practice, 13(2/3), 266-277.

[10] Raheja, GG, ed. (2003). Songs, stories, lives: Gendered dialogues and cultural critique. New Delhi, Kali for Women.

[11] Cornwall, A. (2003). Whose Voices? Whose Choices?
Reflections on Gender and Participatory Development. World Development, 31(8), 1325-1342.

[12] Kapoor, I. (2002). The devil's in the theory: A critical assessment of Robert Chambers' work on participatory development, Third World Quarterly, 23, 101-117.

[13] Harris, O. (1981). Households as natural units, in K. Young et al. (eds), op. cit.

[14] Moore, HL. (1988). Feminism and Anthropology. Policy Press, Oxford.

[15] WIN News (2002). Trickle-Up Program. Women's International Network News. Retrieved from http://www.trickleup.org.

[16] Chambers, R. (1994). The origins and practice of participatory rural appraisal, World Development, 22(7), 953-969.

[17] Rostami-Povey, E. (2007). Gender, Agency and Identity, the Case of Afghan Women in Afghanistan, Pakistan, and Iran, Journal of Development Studies, 43(2), 294-311.

[18] Molyneux, M. (1985). Mobilisation without emancipation? Women's interests, the state, and revolution in Nicaragua, Feminist Studies, 11(2), 227-254.

[19] Moser, C. (1989). Gender planning in the Third World: Meeting practical and strategic gender needs, World Development, 17(11), 1799-1825.

[20] Kandiyoti, D. (2007). Old Dilemmas or New Challenges? The Politics of Gender and Reconstruction in Afghanistan. Development and Change 32(2), 169-199.

[21] Riphenburg, C. (2003). Gender relations and development in a weak state: the rebuilding of Afghanistan, Central Asian Survey, 22 (2/3), 187-207.

[22] Kakar, P. (2005). Fine-tuning the NSP: Discussions of Problems and Solutions with Facilitating Partners. Kabul: Afghanistan Research and Evaluation Unit.

[23] Wakefield, S. (2004). Gender and Local Level Decision Making: Findings from a Case Study in Panjao, AREU Case Study series. Kabul: Afghanistan Research and Evaluation Unit.

[24] Boesen, I. (2004). From Subjects to Citizens: Local Participation in the National Solidarity Programme. AREU Working Paper Series. Kabul: Afghanistan Research and Evaluation Unit.

[25] Kandiyoti, D. (1998). Gender, Power and Contestation: Rethinking "Bargaining with Patriarchy," Feminist Visions of Development: Gender Analysis and Policy, 135-51.

[26] Mosse, D. (1995). Authority, gender and knowledge: theoretical reflections on the practice of Participatory Rural Appraisal. KRIBP Working Paper no. 2, Swansea: Centre for Development Studie.

[27] Zakhilwal, O. (2005). State-building in Afghanistan: A Civil Society Approach. Washington, DC: Centre for International Private Enterprises, Economic Reform Feature Service. 